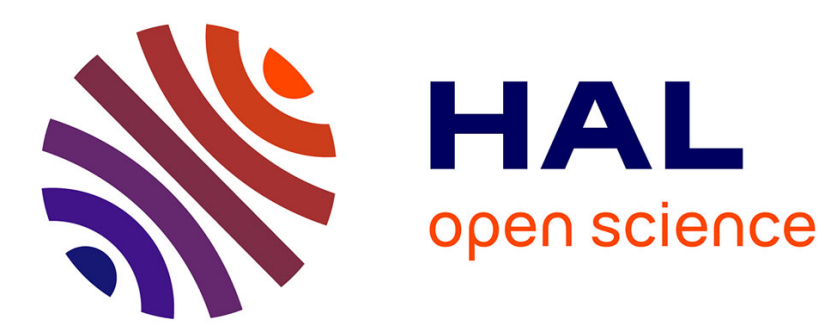

\title{
Partisan Politics in Regional Redistribution
}

Achim Kemmerling, Thilo Bodenstein

\section{To cite this version:}

Achim Kemmerling, Thilo Bodenstein. Partisan Politics in Regional Redistribution. European Union

Politics, 2006, 7 (3), pp.373-392. 10.1177/1465116506066264 . hal-00571731

\section{HAL Id: hal-00571731 \\ https://hal.science/hal-00571731}

Submitted on 1 Mar 2011

HAL is a multi-disciplinary open access archive for the deposit and dissemination of scientific research documents, whether they are published or not. The documents may come from teaching and research institutions in France or abroad, or from public or private research centers.
L'archive ouverte pluridisciplinaire HAL, est destinée au dépôt et à la diffusion de documents scientifiques de niveau recherche, publiés ou non, émanant des établissements d'enseignement et de recherche français ou étrangers, des laboratoires publics ou privés. 


\section{EUP}

European Union Politics

DOI: $10.1177 / 1465116506066264$

Volume 7 (3): 373-392

Copyright@ 2006

SAGE Publications

London, Thousand Oaks CA,

New Delhi

\section{Partisan Politics in Regional} Redistribution

\author{
Do Parties Affect the Distribution of EU \\ Structural Funds across Regions?
}

\section{Achim Kemmerling}

Social Science Research Center Berlin, Germany

\section{Thilo Bodenstein}

Free University of Berlin, Germany

\section{ABSTRACT}

The current debate on the role of regional politics in the European Union (EU) is dominated by approaches that focus upon either intergovernmental bargaining or multi-level governance. Because Structural Funds are the main EU-wide redistributive policy, we propose to apply the traditional literature on partisan politics and national redistribution to the case of the EU. We use a new data set on both the distribution of Structural Funds across regions and the distribution of vote shares for different factions of the European Parliament. These data provide empirical details for some of the partisan competition that takes place at the regional level. Specifically, we show that the traditional left vs. right cleavage can have an impact on the size of regional transfers.

\section{KEY WORDS}

- fiscal federalism

- partisan politics

- redistribution

- structural funds 


\section{Parties as the missing link in regional politics?}

Despite the lively discussion in recent years about the role of political parties in shaping European politics (e.g. Marks and Steenbergen, 2002), the analysis of the role of party politics in determining political outcomes at the European level has yet to develop. Many authors have referred to partisan motives when, for example, explaining treaty revisions, but only recently has there been a literature that systematically evaluates how partisanship affects political outcomes at the European level (Manow et al., 2004). In this vein, the article examines the influence of political partisanship on a specific policy outcome at the European Union level, namely the interregional redistribution in EU Structural Funds (SF) policy.

The current debate on the role of regional politics in the EU is dominated by two strands of argument, neither of which ascribes a central role to political parties. On the one hand, adherents of the intergovernmentalist perspective maintain that the political influence of regional actors is mostly absorbed by the logic of bargaining between national governments (Pollack, 1995; Allen, 2000). On the other hand, scholars devoted to the multi-level governance approach argue that the integration of new policy areas - and especially the development of regional policy in the EU - has introduced regional actors into the evolving political system and created a third level. In particular, the so-called principle of partnership in the governance of SF has aroused considerable academic interest, since it requires that planning procedures are developed in close cooperation with subnational authorities such as local governments or social partners (Evans, 1999).

SF policy is the key mechanism of regional redistribution in the EU for which we propose an alternative route of investigation focusing on the role of (regional) partisan politics. To derive our hypotheses we rely on the traditional literature on partisan politics and redistribution at the national level. Partisan politics may act as a 'missing link' in the debate between the approaches of intergovernmentalism and multi-level governance, because it relates preferences to ideology rather than to the political fissures between national and regional actors. Empirically, we investigate the relationship between regional variation in partisan preferences - left vs. right and proEurope vs. anti-Europe - and the level of SF per capita that the respective regions receive. For this purpose we have constructed a data set that combines regional information on both elections and SF transfers. Our results indicate that there is a visible, though not very robust, relationship between the strength of left-wing political parties in a region and the size of the transfers that region receives. We also find a similar link between Eurosceptic parties and transfers, but this result is more sensitive to influential outliers. 


\section{Regional partisan politics applied to EU regional policy}

Most political scientists agree that political parties play a pivotal role at the national level. Parties represent the ideological cleavages within the electorate, and should therefore affect policy. EU studies, however, are dominated by functionalist, institutionalist or intergovernmentalist approaches in which political parties are not at the centre of analysis. Research on parties in the EU has therefore focused mainly on either European elections (Van der Eijk and Franklin, 1996) or the formation of the party system in the European Parliament (Hix and Lord, 1997). Because the consequences of partisan politics for EU policies have remained largely unnoticed, we will first explore the literature of partisan preferences and redistribution at the national level. Next, we will compare the SF policy of the EU with national redistribution. Finally, we will derive two hypotheses that link partisan politics and interregional redistribution in the EU.

\section{Partisan politics and national redistribution}

It is not at all obvious that partisan ideology can be 'mapped' into preferences for redistribution at a national level. In fact, the standard Downsian approach to political competition argues that parties should completely converge and that the size of redistribution depends merely on the characteristics of the median voter. An example is the hypothesis that the size of redistribution is determined by the relationship between median and mean income in a society (Meltzer and Richard, 1991). Wittman (1983) was one of the first to propose an alternative model that allows for ideological partisan preferences. Roemer (2001: 72) takes up his idea and shows that divergence between partisan manifestos is likely only if the Wittman model assumes uncertainty about the precise distribution of voter preferences.

The partisan argument has figured prominently in numerous empirical studies that investigate the amount of welfare spending in advanced economies (Huber et al., 1993), the specific form of redistributive policies implemented (Boix, 1998) or the link between party manifestos and the policies of incumbent parties (Klingemann et al., 1994). The empirical record is ambivalent, however, since a simple mapping of partisan ideology into policy output is difficult. First, the ideological structure of the 'voter space' may go beyond a simple one-dimensional division between 'left' and 'right'. Second, political institutions affect the aggregation of voters' preferences. It has been argued, for instance, that proportional or multi-party systems spend more money on redistribution than do majoritarian ones (Persson, 2002).

The second point is particularly relevant for multi-tier political systems 
that are characterized by a complicated decision-making process of fiscal federalism. The addition of a cleavage between different political layers makes theoretical predictions fairly difficult (e.g. Dixit and Londregan, 1998; Persson, 2002). Depending on the specific nature of the federalist institutions, subnational entities may have an incentive to extract rents from the central government. However, this effect is not unambiguous because decentralization arguably reduces the total level of rent extraction (see Rodden and Wibbels, 2002). In particular, the political economy of fiscal federalism does not render the partisan argument obsolete. For instance, Cadot et al. (2002) build a model that combines both partisan and pork-barrel politics in a model for national regional policy.

To conclude, the partisan model of public redistribution is far from flawless, but it remains the strongest competitor to political economy-based explanations along the lines of Anthony Downs. It clearly constitutes a simplification, but it deserves consideration as a parsimonious explanation of interregional redistribution in the EU.

\section{Comparing national and EU-wide politics of interregional redistribution}

EU regional policy fulfils the classic criteria of a redistributive policy. This is visible in the overall objectives governing the distributive mechanism, which have been reorganized under the recent Agenda 2000 reform into three focal areas: 'Objective 1 ' for the development of regions that are lagging behind in their economic development; 'Objective 2' for regions with declining industrial and rural sectors; and 'Objective 3 ' for the promotion of skill and employment policies in regions other than for 'Objective 1'. To qualify for Objective 1 , the per capita GDP of a region must lie below $75 \%$ of the EU average. Objective 2 covers industrial regions with an unemployment rate above the EU average and a declining employment rate in the manufacturing sector.

The fact that Objective 1 is given clear financial priority shows the dominance of redistribution from rich to poor regions. Although the total amount of SF is not particularly large - around $0.3 \%$ of the GDP of the EU - it is significant for some regions. Regional redistribution in the EU currently accounts for one-third of the budget of the European Union. In the period 2000-6, the regions that receive most SF on a per capita basis are Madeira, with $€ 2870$ and the Azores, with €3590. These facts, taken together, show that, among all EU policies, SF are most directly comparable to national redistributive mechanisms.

The EU decision-making process is more complex and dynamic than national systems of fiscal federalism. The governance of SF has been evolving 
over the past two decades as a result of major reforms in 1988, 1992-3 and 1999 (Bache, 1998; Bailey and De Propris, 2002). Its complexity stems from several principles governing the allocation of regional transfers. One of these principles is 'additionality', which requires that SF transfers do not supersede national regional aid. Some scholars have argued that this principle was advocated primarily by regional actors and the Commission (Bache, 1998) in order to increase their budgets. ${ }^{1}$ It is difficult, however, for the Commission to monitor nation-states on grounds of additionality (Allen, 2000: 257) since the implementation of structural policies is in the domain of nation-states. Another important principle is 'partnership'. According to it, planning procedures for SF should be developed in cooperation with subnational actors, such as local governments and social partners (Hooghe, 1998; Evans, 1999). However, the 1988 reform granted a strong position to the Commission, which needs to approve the eligibility of a region under Objectives 1 and 2 (Hooghe and Keating, 1994). This seems to override the influence of subnational actors on the shaping of EU Structural Funds policy (Allen, 2000).

Furthermore, national and EU-level politics differ, ${ }^{2}$ and there is an important debate about how to structure the political space in Europe (Hix and Lord, 1997; Gabel and Anderson, 2002). One of the crucial questions is whether there is an independent 'pro-EU' vs. 'anti-EU' cleavage alongside the traditional left vs. right cleavage. There is evidence that these two cleavages are at least not perfectly collinear, in that the EU topic becomes more and more established as a dimension of its own (Marks and Steenbergen, 2002). In this case, the redistributive logic of SF policies may not be a conflict just between richer and poorer regions. There are Eurosceptic parties at the regional level, mostly consisting of smaller and ideologically more radicalized parties (Taggart and Szczerbiak, 2002). If Eurosceptic parties represent the losers from political integration, such as in those regions that benefit very little from the common market or monetary union, then they may have an impact on political outcomes. Boeri et al. (2002) argue that EU regional policy is aimed at precisely those regions that stand apart from the prospering core areas of economic integration. Hence, if there is an element of compensation attached to the distribution of SF, it may well be that this is a consequence of regional parties voicing their unease about integration.

All in all, SF policy is primarily about redistribution from rich to poor or declining regions. The bargaining and monitoring process of SF policy is rather complex, because it requires the interaction of three levels of government in accordance with the principles mentioned above and the set of criteria for Objectives 1 and 2. Moreover, the underlying voter space differs in one respect from national politics: there is a cleavage between pro- and antiEuropean positions. This cleavage arguably plays a minor role in national 
redistribution but it has to be kept in mind when we apply the partisan hypothesis to the bargaining on regional redistribution in the EU.

\section{The bargaining process and channels of partisan influence on SF policy}

There are two different logics embedded in the bargaining process. On the one hand, the Commission, the Council and the regional actors bargain over the selection of regions. On the other hand, regional actors try to influence the distribution of SF in a country. Both processes are intertwined, but they do not necessarily follow the same logic, as a closer inspection of the institutional rules shows. ${ }^{3}$ The Council of Ministers first drafts a budgetary envelope for each Objective. The Commission then uses so-called 'transparent procedures' (i.e. official criteria) to distribute the budget between member states. Since not all of these criteria are operationalized in detail, the Commission has some discretionary power. However, the rule that national governments provide the short-lists of regions to the Commission limits this leeway. In the structural programming phase, the national governments and regional actors cooperate in designing specific development plans for each and every region. Member states must compile a selection of eligible Objective 1 and 2 regions with corresponding financial allocations. Once the plans are elaborated, the Commission and member states transform the plans into binding legal commitments. ${ }^{4}$

Moreover, the 1999 bargaining process was embedded in negotiations on the general budgetary process for the period 2000-6. This meant that there was simultaneous bargaining on the size of the national shares between national governments (Heinelt et al., 2005: 116). The link between the two processes is arguably the selection of regions to qualify for SF, since this determines the size of national budgets. Intergovernmental negotiations on the EU budget have been studied extensively by many authors (Rodden, 2002; Kauppi and Widgrén, 2004; Zimmer et al., 2005). In contrast to these studies, we are interested in the regional and not the national redistribution of SF. To simplify the following analyses we focus on the impact that parties have on the amount of regional transfers once national SF shares have been negotiated. Making this assumption allows us to abstain from dealing extensively with the various package deals between agricultural, cohesion and structural transfers, as well as the debate about the net payment position of countries. This assumption is problematic in that the selection of regions (for which international bargaining is important) and the allocation of funds (for which interregional bargaining is important) necessarily affect each other. Nevertheless, it has some empirical foundation, since the Berlin summit in 1999 yielded 
an agreement on the national distribution of SF but the precise regional allocation of SF was negotiated afterwards (Heinelt et al., 2005: 131).

Partisan politics at a regional level can intrude on this decision-making process at the level of regional transfers through two political channels. Regional actors can lobby either the next higher national level or the EU institutions directly. The former is a common phenomenon in national federalist systems. For example, the prime ministers of German federal states are aware of the redistributive consequences of changes in SF policy for their own electorates. They have acted as crucial veto players for the German central government when the latter aimed at reducing the size of spending on SF during the Berlin summit in 1999 (Heinelt et al., 2005: 179). Partisan bonds between regional and central governments have been shown to be important determinants of the allocation of national investment policies (Kemmerling and Stephan, 2002). It is reasonable to assume a similar tendency at the EU level. National policy-makers have to take the distributional consequences of changes in SF policy into consideration. The more that partisan channels transmit these consequences, the more likely it is that policy-makers will take them into consideration.

Stronger subnational entities, such as German or Austrian Länder, have also approached the EU Commission directly (Jeffrey, 1996). All German Länder have their own representations in Brussels, which shows that this direct lobbying is seen to be a beneficial investment. The principle of partnership establishes such political communication officially, since the Commission actively seeks to engage with subnational tiers of the political system. As a consequence, lobbying by regions in Brussels has increased (Allen, 2000: 259). Local authorities, and with them partisan actors, not only cooperate with national governments in the planning and monitoring stages, but also intervene in the policy process via a host of formal and informal committees such as the Economic and Financial Committee (ECOFIN), the Council of Regional Ministers and the Committee of Regions and Local Authorities.

These channels allow regional partisan actors to participate in the negotiations between the Commission and the member states. We summarize this discussion in the form of two main hypotheses that link the underlying political space in the European Union with redistributional outcomes in SF policies.

H1: Regions in which parties on the left of the spectrum are strong should receive more Structural Funds than other regions.

The distribution of Structural Funds across regions should correspond to traditional partisan preferences for more or less spending. The causal mechanism for this hypothesis is analogous to that for national political systems. According to their ideologies, parties from the left always prefer higher levels 
of spending than do parties on the political right. This hypothesis is a typical marginal argument. All else being equal, we expect left-wing parties to receive more SF per capita than right-wing parties. Obviously, any regional government will try to maximize its own revenues. Given their ideological stance, however, left-wing parties should be more capable of doing so since this corresponds to the ideological preferences of their voters (Roemer, 2001). Because SF are the EU's major redistributive tool that is directly comparable to national redistribution, these preferences should be visible in the form of higher levels of SF.

H2: If a pro-EU vs. anti-EU cleavage exists, regions in which Eurosceptic parties are strong will receive more Structural Funds in order to buy the political acquiescence of these voters.

The causal mechanism for the second hypothesis is more complicated. We expect that SF policy does not (only) serve the purpose of enhancing socioeconomic cohesion. We rather think of SF policy as a means of compensating political losers or those who protest against EU integration. If this is the case, it is reasonable to assume that major parties and political actors have to pacify Eurosceptic voters through substantial transfers. A good example is Ireland, which is one of the countries that have received most SF on a per capita basis. Until the mid 1990s, Ireland received up to 5\% of national GDP in annual transfers for cohesion and restructuring. Most Irish are in favour of the EU as Eurobarometer data show - but this does not deter them from voting against crucial reforms when national politics overrides EU issues, such as in the case of the Nice Treaty in the referendum of June 2001. In these cases, SF could act as a political compensation for voters' agreement on further steps in European integration. ${ }^{5}$

If the institutional critique is correct, both hypotheses depend on the institutional characteristics of national political systems. Hence, it is possible that partisan effects are stronger in federalist political systems where regional actors have more political clout than they do in centralized systems (Hooghe and Keating, 1994). It is also likely that partisan effects are stronger if the same party rules on different levels of government. Given the complexity of the EU's political system, our hypotheses are highly stylized. They are, however, the closest analogy to similar studies done on national redistributive policies. The next section will show how these hypotheses are operationalized.

\section{Descriptive empirics and data}

In this section we introduce indicators measuring regional partisanship and the SF received per subnational unit. Given the huge diversity of national 
political systems in the EU, both variables are difficult to operationalize. We turn first to the partisan variables, for which data from the 1999 elections to the European Parliament are used. To measure SF allocation at the regional level, we use the official data of the EU Commission's financial budgetary planning for the period 2000-6. Here we focus primarily on a short description of how these Funds are allocated across EU regions.

\section{Data on regional partisan cleavages}

Measuring the regional distribution of different party families across Europe is a daunting task. Not only are party families in some instances characterized by high internal heterogeneity and temporal instability (see e.g. Hix and Lord, 1997), but systems of regional classification also differ widely across Europe. We therefore decided to gather data for the 1999 European Parliamentary election for 116 regions. Using data on EP elections has some advantages over national data, since they reveal the actual voting behaviour at the same point in time for all countries. We computed the vote share of parties for the regional level corresponding to the EU's NUTS classification. ${ }^{6}$ For Portugal and Finland we could not match the national administrative system of election statistics with the NUTS classification, and so we had to leave these countries unaccounted for.

Comparing party votes across European regions is naturally problematic. In order to enable a meaningful comparison, we linked each national party to its corresponding party faction in the European Parliament. All in all, there were seven party families represented in the EP between 1999 and 2004. The British Labour Party, for example, is part of the Socialist Group in the European Parliament (PES). For all these parties we report their votes received according to region in national elections and in the European elections, respectively. If two leftist parties in a region were members of the same faction in the EP, we added both percentage votes. With this procedure we have lost the information on individual parties, but we have gained comparability across European regions and elections.

The two variables of major interest are the sizes of left parties and Eurosceptic parties in regional elections (LEFTPAR and ESCEP). We defined the following European party factions as being part of a leftist party family: the Party of European Socialists Group, the Confederal Group of the European United Left/Nordic Green Left, and the Greens/European Free Alliance Group. The share of Eurosceptic parties contains the regional votes for the following factions: the Confederal Group of the European United Left/Nordic Green Left, Union for Europe of the Nations, the Group for a Europe of Democracies and Diversities, the Technical Group of Independent Members, and factionally independent EP members. Note that, according to our coding, 
the Confederal Group of the European United Left/Nordic Green Left is part of both the leftist and the Eurosceptic group. In order to provide an idea of party competition in European regions, we added the Effective Number of Parties (ENP). ENP is a Herfindahl index and is defined as the inverse of the sum of squared party shares. The appendix shows the summary statistics for our variables of interest for the European elections. ${ }^{7}$

\section{Data on Structural Funds}

Data on SF originate from the DG Budget of the EU Commission and represent the financial perspective of the distribution of SF for the years 2000-6. We extracted information on Funds for Objectives 1 and 2, which are the only fiscal transfers that can be attributed to individual regions. Funds for these two objectives make up roughly $70 \%$ of total spending on SF. Unfortunately, the Commission does not report data at the same aggregation level in all countries, but in some instances uses NUTS 1, NUTS 2 or even the national level. This is due to the administrative structure of each member state. Ireland, for instance, counts as a single Objective 1 region, whereas in Germany the beneficiaries are the Länder (NUTS 1). In France, recipients of Objective 1 Funds are the Régions, which correspond to NUTS 2. All together, we gathered information for 83 out of a total 137 European regions that receive Objectives 1 and 2 funding.

SF are officially allocated according to transparent criteria such as, for Objective 1 Funds, the 75\% average EU GDP threshold or, for Objective 2 Funds, the status of being an industrial region in decline. SF allocations, however, correlate only weakly with these official indicators. Figure 1 shows the relationship between SF and GDP per capita. We use the sum of per capita Objective 1 and 2 Funds per region and show its relation to GDP per capita at the regional level. ${ }^{8}$ Obviously, there is a negative relationship between these two variables, but 'being poor' is neither a strong nor a sufficient predictor of the amount of SF per head a region receives, as the upper-left observations and the outlier of Ireland show. If we were to use other information, such as the per capita level of agricultural funds, we would also not find a particularly strong relationship. There is a trade-off between Structural and Agricultural Fund spending, but regional diversion along this trade-off is high. Our conjecture is that partisan politics explains some of this residual variation.

\section{Testing the hypotheses}

This section provides an empirical test for the two partisan hypotheses. We are interested in how far partisan politics shapes the regional allocation of SF 


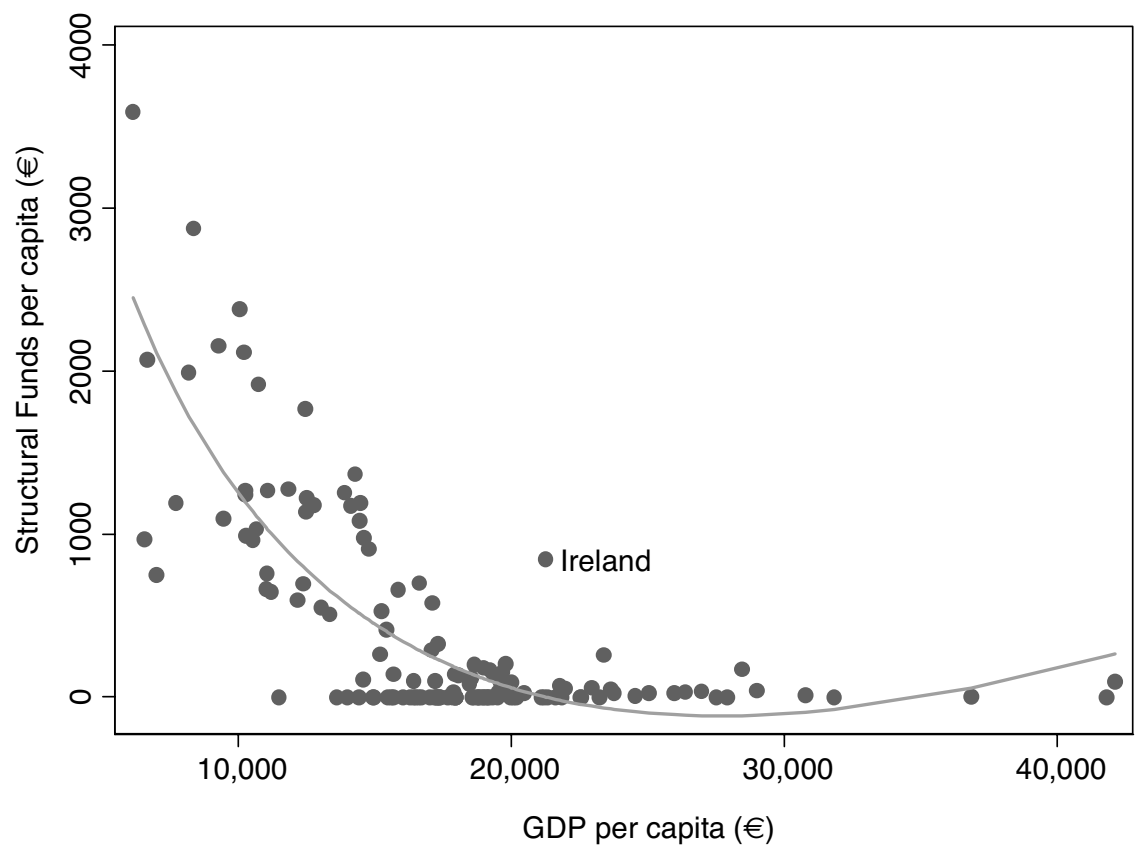

Figure 1 Regional distribution of Structural Funds and GDP per capita.

in Europe. Therefore the effects of two different sets of variables are explored. First, official economic criteria such as per capita GDP (GDP/CAP) for 'Objective 1 ' and the unemployment rate (UNEMP) for 'Objective 2' should have an impact on the allocation of SF per capita. In addition, SF should be complementary to Agricultural Funds per capita. Unfortunately, only national shares of agricultural transfers (AGRAR/CAP) are available. Second, we consider the notion that partisan politics also influences the allocation of SF. Our main interest lies in testing the impact of the size of left parties (LEFTPAR) and Eurosceptic parties (ESCEP) on the allocation. We expect both variables to raise regional SF.

Some scholars argue that partisan politics should play a role only where political institutions allow regional actors to be influential (Hooghe and Keating, 1994). We therefore add two indicators as proxies for institutional effects. One is the Effective Number of Parties (ENP). It has been argued that proportional voting systems usually generate more effective political actors than do majoritarian systems, and are therefore biased towards more spending (e.g. Persson and Tabellini, 2004). The reason is that coalition governments are more likely in multi-party systems, and these coalitions are difficult to form without further spending. The second indicator is a proxy for the presence of federalist systems (FED). As outlined earlier, federalist 
systems grant more influence to subnational actors, which should in turn lead to more spending for these regions. We used a dummy variable from Persson and Tabellini (2003), where federal systems are coded with 1.

We tested our hypotheses with the data set on SF and the results of the 1999 European elections. The previous section showed that these partisan data are a reasonable way of depicting regional-level political cleavages, no matter how 'second order' elections to the EP are supposed to be. Electoral patterns are similar enough to enable meaningful interpretations to be drawn from the European elections. In addition, because of data constraints for national elections, we increase the number of observations by using the European election data. The appendix shows the summary statistics of our variables.

The estimation method is ordinary least squares (OLS) with the logarithm of the SF per capita (log OBJ/CAP) as the dependent variable. Our dependent variable is, however, truncated. Many European regions receive no SF at all, which might lead to biased results if we were to include all observations in our regression and not just those regions receiving SF. A standard remedy for this problem is the use of a Tobit model. As Hug (2003: 263) argues, the truncated regression is preferable if important omitted variables influence simultaneously the selection into the incomplete data set and the dependent variable of the outcome equation'. As argued above, it is unlikely that the bargaining processes for selecting regions and distributing SF are the same. In such circumstances, it is difficult to establish whether the Tobit results are always superior to OLS. Ideally, one would use a selection model that explicitly accounts for differences in the selection and distribution stages, but this is beyond the scope of this paper. ${ }^{9}$ Therefore we present both OLS and Tobit results in Table 1.

The first model estimates the effects of our main independent variables. We include three variables that depict the official allocation criteria (GDP/CAP [log], UNEMP [log] and AGRAR/CAP [log]) in addition to Federalism (FED) and the Effective Number of Parties (ENP) as control variables. As expected, GDP per capita has a negative and strongly significant impact on the regional allocation of SF. The sign of the coefficient of the unemployment rate (UNEMP) is positive but insignificant. The allocation of Agricultural Funds per capita (AGRAR/CAP) has a positive coefficient, suggesting that beneficiaries of Agricultural Funds also receive more SF. The variable, however, is far from being significant. Our partisan variables confirm our hypotheses. The share of left parties in the European elections at the regional level (LEFTPAR) and the share of Eurosceptic parties (ESCEP) have the expected positive signs and are also significant at the $10 \%$ level. Apparently, the strength of left and Eurosceptic parties adds substantial information to 
Table 1 Regression results for Structural Funds and partisan politics

\begin{tabular}{|c|c|c|c|c|}
\hline & $\begin{array}{l}\text { Model } 1 \\
\text { OLS }\end{array}$ & $\begin{array}{l}\text { Model } 2 \\
\text { OLS }\end{array}$ & $\begin{array}{l}\text { Model } 3 \\
\text { OLS }\end{array}$ & $\begin{array}{l}\text { Model } 4 \\
\text { Tobit model }\end{array}$ \\
\hline Constant & $\begin{array}{l}33.758^{* * *} \\
5.96\end{array}$ & $\begin{array}{l}35.065^{* * *} \\
(6.2)\end{array}$ & $\begin{array}{l}31.089 * * * \\
(5.21)\end{array}$ & $\begin{array}{c}9745.255^{* *} \\
(3.34)\end{array}$ \\
\hline GDP/CAP (log) & $\begin{array}{l}-3.074^{* * *} \\
(-6.01)\end{array}$ & $\begin{array}{l}-3.232^{* * *} \\
(-6.28)\end{array}$ & $\begin{array}{l}-2.862^{* * *} \\
(-5.39)\end{array}$ & $\begin{array}{c}-1032.7 * * * \\
(-3.91)\end{array}$ \\
\hline UNEMP (log) & $\begin{array}{c}0.21 \\
(0.85)\end{array}$ & $\begin{array}{l}0.077 \\
(0.3)\end{array}$ & $\begin{array}{r}0.367 \\
(1.35)\end{array}$ & $\begin{array}{c}294.006^{*} \\
(2.27)\end{array}$ \\
\hline AGRAR/CAP (log) & $\begin{array}{c}0.009 \\
(0.03)\end{array}$ & $\begin{array}{c}0.114 \\
(0.37)\end{array}$ & $\begin{array}{c}0.089 \\
(0.29)\end{array}$ & $\begin{array}{c}143.463 \\
(0.9)\end{array}$ \\
\hline LEFTPAR & $\begin{array}{l}2.949^{*} \\
(2.57)\end{array}$ & $\begin{array}{l}3.097^{* *} \\
(2.72)\end{array}$ & $\begin{array}{c}2.394 \\
(1.98)\end{array}$ & $\begin{array}{c}151.122 \\
(0.27)\end{array}$ \\
\hline ESCEP & $\begin{array}{l}3.061^{*} \\
(2.55)\end{array}$ & $\begin{array}{l}2.827^{*} \\
(2.37)\end{array}$ & $\begin{array}{c}2.392 \\
(1.86)\end{array}$ & $\begin{array}{c}107.54 \\
(0.2)\end{array}$ \\
\hline FED & $\begin{array}{l}-0.47 \\
(-1.8)\end{array}$ & $\begin{array}{l}-0.556^{*} \\
(-2.11)\end{array}$ & $\begin{array}{c}-0.261 \\
(-0.86)\end{array}$ & $\begin{array}{r}197.49 \\
(1.57)\end{array}$ \\
\hline ENP & $\begin{array}{c}-0.106 \\
(-0.77)\end{array}$ & $\begin{array}{l}-0.104 \\
(-0.76)\end{array}$ & $\begin{array}{l}-0.063 \\
(-0.45)\end{array}$ & $\begin{array}{c}-219.248^{* * *} \\
(-3.89)\end{array}$ \\
\hline LEFTPAR $\times$ FED & & $\begin{array}{c}3.884 \\
(0.114)\end{array}$ & & \\
\hline ESCEP $\times$ FED & & & $\begin{array}{l}2.813 \\
(1.36)\end{array}$ & \\
\hline$N$ (censored) & 71 & 71 & 71 & $116(71)$ \\
\hline Adj. $R^{2}$ & 0.7301 & 0.7367 & 0.7337 & \\
\hline$F$-test & $28.06 * * *$ & $25.49 * * *$ & $25.11 * * *$ & \\
\hline LR Chi² & & & & $87.28 * * *$ \\
\hline Log likelihood & & & & -567.971 \\
\hline Pseudo $R^{2}$ & & & & 0.0714 \\
\hline
\end{tabular}

Notes: $t$-values in parentheses; ${ }^{*}$ significant at $10 \% ;{ }^{*}$ significant at $5 \% ;{ }^{* *}$ significant at $1 \%$.

the puzzle of SF allocation. Partisan politics also explains the outlier of Ireland in Figure 1, because Ireland has strong Eurosceptic parties. As for our two institutional variables, we see that neither the federalism (FED) nor the multiparty system indicator (ENP) performs particularly well. Since we lack partisan data for some regions, the number of observations amounts to 71 in models 1 to 3 . We also tested for correlation between the independent variables but failed to find strong correlations.

Based on the coefficients in model 1 we see that a 1 percentage point increase in the vote share of left parties increases the allocation of SF by $2.9 \%$. An increase in Eurosceptic parties by 1 percentage point increases the regional 
allocation by as much as 3\%. The appendix contains two partial plots for the effects of LEFTPAR and ESCEP in model 1. The visual inspection shows that the partial residuals of LEFTPAR are robust against outliers, whereas ESCEP, though not unreliable, is more sensitive. However, one caveat applies. It is possible that regional voter behaviour might be influenced by the amount of $\mathrm{SF}$ a region receives. If this were the case, the causal effect could be reversed. In fact, Mattila (2003) shows that turnout in European elections is influenced by the EU subsidies a country receives, although this effect is not very strong. If, on the other hand, subsidies had an impact on voter behaviour, we would underestimate rather than overestimate the coefficients of our main independent variables.

We also tested for interaction effects in models 2 and 3. In particular, we test whether the impact of left and Eurosceptic parties on SF allocation is contingent on the degree of federalism. In order to construct our interaction terms LEFTPAR $\times$ FED and ESCEP $\times$ FED, we re-parameterized the variables by subtracting the means from LEFTPAR, ESCEP and FED before multiplying these variables. This has the advantage that the coefficients of LEFTPAR and ESCEP in models 2 and 3 depict their effects for the mean value of FED. Model 2 shows that including LEFTPAR $\times$ FED as interaction term slightly improves the significance and size of the coefficient of LEFTPAR, although the interaction term is insignificant. In model 3, the interaction term ESCEP $\times$ FED affects the significance of LEFTPAR and reduces the coefficient and significance of ESCEP. ${ }^{10}$

The fourth model is our Tobit estimate. We use SF per capita rather than its logarithm as the dependent variable. All of the 116 European regions for which we have data go into the regression. The Tobit model results show at first glance that all coefficient signs, except for FED, remain stable. Further inspection shows that all $t$-values stay in a similar range compared with the $t$-values of model 1 , and even with the $t$-values of the OLS model with the non-logarithm dependent variable (not displayed). Only the effective number of parties (ENP) changes its $t$-value and significance level compared with model 1. LEFTPAR and ESCEP lose their significance in the Tobit model. We cannot give a definitive answer as to which OLS or Tobit regression better suits the data. The Tobit model corrects for truncated data, whereas our OLS regression fits the skewed distribution better for regions receiving SF, using the dependent variable logarithm. We argue, however, that the explanatory power of our main independent variables, LEFTPAR and ESCEP, applies only to those regions that receive at least some SF. We do not claim that the vote share of Eurosceptic or left parties explains why a region that is not officially eligible does not receive any funding.

Figure 2 shows that there is indeed no correlation between the share of 


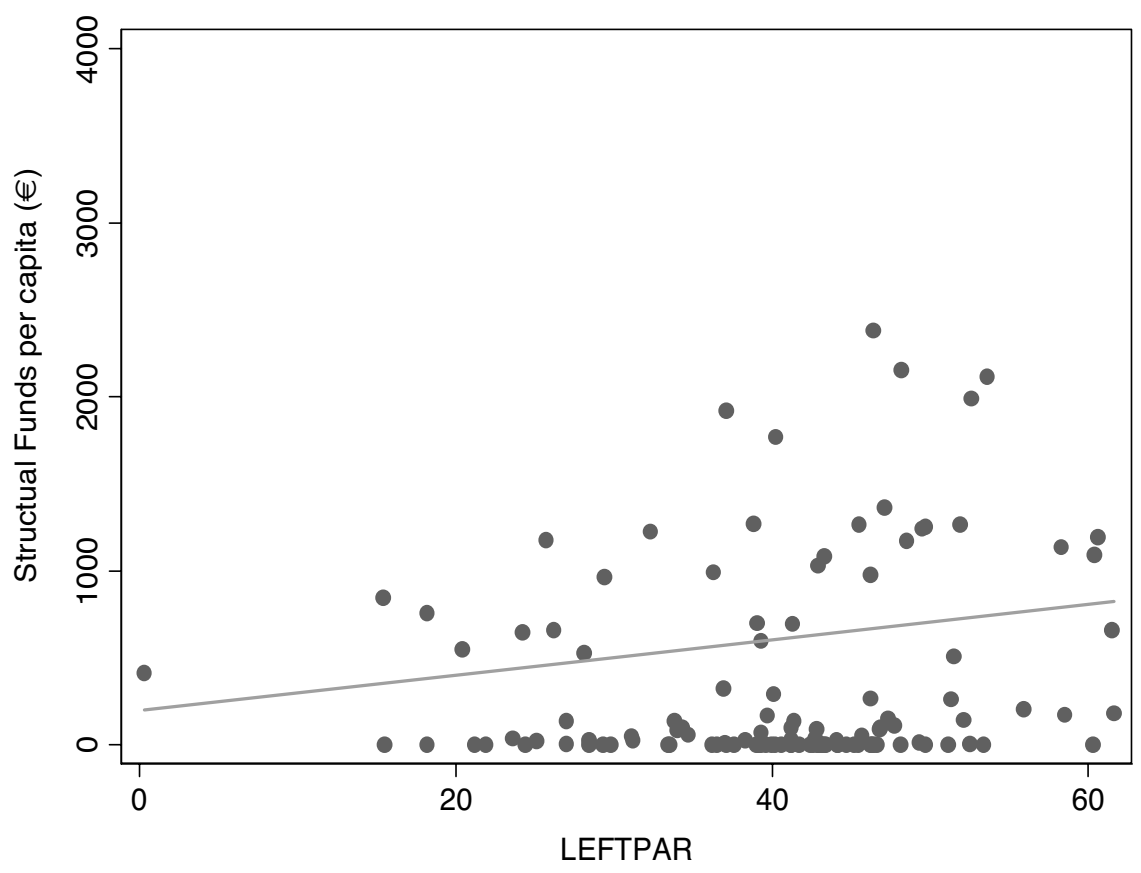

Figure 2 Vote share of left parties and Structural Funds per capita.

left parties and SF allocation for those regions that are not eligible for funding. For the eligible regions, however, there is a strong positive correlation. The figure displays the regression line only for the regions receiving SF. We therefore conclude that party politics matters in regions that are eligible for funding. However, the relationship between eligibility for SF and partisan politics is unlikely to be equivalent to the relationship between the distribution of SF and partisan politics. Here, official criteria such as GDP per capita and the unemployment rate would need to be addressed in detail. Moreover, our dependent variable data are not exactly suitable for the Tobit model. Since addressing the selection bias is not without caveats either (Bodenstein and Kemmerling, 2004), there is no clear strategy for which model should be preferred. We therefore regard only the OLS estimates as inferences for those regions that actually qualify as SF regions.

\section{Conclusions}

This paper has explored the impact of European partisan politics on the allocation of SF in subnational European regions. There is an ongoing debate 
about which political actors at different political levels shape European SF policy, and whether this policy field is giving rise to a new mode of European governance. Partisan politics does not play a major role in this literature. At the national level, in contrast, partisan explanations for redistributive preferences are fairly widespread. This insight prompted us to delve deeper into the impact that European party politics has on SF policy, a core European redistributive policy area.

We have argued that partisan politics can influence the allocation of SF in at least two ways. First, regional parties can affect the behaviour of subnational or national governments. If a region is dominated by parties with a high ideological preference for regional policy, regional politicians will lobby for SF harder than will national governments. Second, regional partisan actors can lobby the EU Commission and other European actors directly. To the extent that the EU Commission has discretionary power over the distribution of SF, strong regional actors can try to influence the distribution of these funds directly. Given these two channels, party composition is likely to influence the allocation of SF. Therefore we applied the traditional partisan hypothesis from the literature on national redistribution and have found visible, though not always robust, evidence for a link between partisanship and SF policy at the regional level.

Studies on European distributional policies primarily focus on redistribution between EU member states and assess the role that negotiations in the Council of Ministers play in this process. This paper has shifted the focus to subnational actors, especially in the regions, and has explored the role of parties instead of governments. Thus far, interregional redistribution has rarely been addressed, despite its normative importance in the European Union. If, for instance, interregional redistribution is really driven by political or institutional factors, this may be one reason Structural Funds have proved ineffective in economic terms (e.g. Boeri et al., 2002). This implies that the abolition of Structural Funds, as suggested by some economists, would lead to serious political problems in particularly sensitive regions.

\section{Notes}

We would like to thank Thomas Plümper, Gerald Schneider, Philipp Mohl and the three anonymous reviewers for their comments.

1 A further complication is that the Commission deals with a diverse set of subnational actors. National governments select subnational partners, with the result that the implementation of the partner principle varies across EU member states (e.g. Sutcliffe, 2000). 
2 A further caveat is that European issues are of low political salience. Elections for the European Parliament (EP) are generally considered to be secondorder competitions (Reif, 1984). We address this issue in the empirical section of the paper.

3 For the financial period 2000-6, the decision procedure follows Council Regulation (EC) 1260/1999 of 21 June 1999.

4 Although the EP has gained in importance through the Amsterdam Treaty, its discretionary power to change the list of regions or transfers to specific regions is limited (Heinelt et al., 2005). It can, however, lobby the Council and the Commission in the name of regional interests in the wake of important summits.

5 Mattila (2003), for instance, finds that voter turnout in EP elections responds positively to the size of the EU transfers a country receives.

6 The NUTS classification (Nomenclature des Unités Territoriales Statistiques) is the standardized classification of subnational unities in the European Union. It distinguishes between three hierarchical regional levels, which do not necessarily coincide with real administrative units.

7 We have compared our regional election data for the EP with the respective regional election data for national elections preceding the EP 1999 elections (Caramani, 2000). T-tests for the variables of both elections show that the differences are marginal. Even though EP elections are less salient politically, this does not affect the regional variation in partisan cleavages. We conclude that data from the EP elections are suitable for our purpose. Both our data set and the appendix are available on the EUP homepage (http://www. uni-konstanz.de/eup/issues.htm).

8 We could not include spending on Objective 3, since the EU Commission does not provide the necessary information for the regional level. Its overall importance is, however, marginal compared with Objectives 1 and 2.

9 An alternative model to control for selection bias would be a Heckman selection model. However, this necessitates a thorough understanding of what drives the process of granting a region the status of an SF beneficiary in general. Since we lack a theory for this selection process, we refrain from using the Heckman model.

10 We have also experimented with further interactions. There is a weak incidence that the party system and the congruence between national and European elections enhance the partisan effects. Results are available on request.

\section{References}

Allen, David (2000) 'Cohesion and the Structural Funds: Transfers and Trade-Offs', in Helen Wallace and William Wallace (eds) Policy-Making in the European Union, pp. 243-65. Oxford: Oxford University Press.

Bache, Ian (1998) The Politics of European Union Regional Policy: Multi-level Governance or Flexible Gatekeeping? Sheffield: Sheffield Academic Press.

Bailey, David and Lisa De Propris (2002) 'The 1988 Reform of the European 
Structural Funds: Entitlement or Empowerment?', Journal of European Public Policy 9(3): 408-28.

Bodenstein, Thilo and Achim Kemmerling (2004) 'Ripples in a Rising Tide: Why Some EU Regions Receive More Structural Funds Than Others', Paper presented at the ECPR Joint Sessions of Workshops, Uppsala, 13-18 April.

Boeri, Tito, Guiseppe Bertola, Herbert Brücker and Fabrizio Coricelli (2002) ‘Who's Afraid of the Big Enlargement? Economic and Social Implications of the European Union's Prospective Eastern Expansion', CEPR Policy Papers No. 7.

Boix, Carles (1998) Political Parties, Growth and Equality: Conservative and Social Democratic Economic Strategies in the World Economy. Cambridge: Cambridge University Press.

Cadot, Olivier, Lars-Hendrik Röller and Andreas Stephan (2002) 'Contribution to Productivity or Pork Barrel? The Two Faces of Infrastructure Investment', WZB discussion papers FS IV 02-09.

Caramani, Daniele (2000), Elections in Western Europe since 1815: Electoral Results by Constituencies. London/New York: Macmillan/Grove's Dictionaries.

Dixit, Avinash and John Londregan (1998) 'Fiscal Federalism and Redistributive Politics', Journal of Public Economics 68: 153-80.

Evans, Andrew (1999) The EU Structural Funds. Oxford: Oxford University Press.

Gabel, Matthew J. and Christopher J. Anderson (2002) 'The Structure of Citizen Attitudes and the European Political Space', Comparative Political Studies 35(8): 893-913.

Heinelt, Hubert, Tanja Kopp-Malek and Jochen Lang (2005) Die Entwicklung der EU-Strukturfonds als kumulativer Politikprozess. Baden-Baden: Nomos.

Hix, Simon and Christopher Lord (1997) Political Parties in the European Union. London: Macmillan.

Hooghe, Liesbet (1998) 'EU Cohesion Policy and Competing Models of European Capitalism', Journal of Common Market Studies 36(4): 457-74.

Hooghe, Liesbet and Michael Keating (1994) 'The Politics of European Union Regional Policy', Journal of European Public Policy 1(3): 367-93.

Huber, Evelyne, Charles Ragin and John D. Stephens (1993) 'Social Democracy, Christian Democracy, Constitutional Structure, and the Welfare State', American Journal of Sociology 99(3): 711-49.

Hug, Simon (2003) 'Selection Bias in Comparative Research: The Case of Incomplete Data Sets', Political Analysis 11(3): 255-74.

Jeffrey, Charlie (1996) 'Regional Information Offices in Brussels and Multi-level Governance in the EU: A UK-German Comparison', Regional and Federal Studies 5(3): 356-65.

Kauppi, Heikki and Mika Widgrén (2004) ‘What Determines EU Decision Making? Needs, Power or Both?', Economic Policy 19(39): 221-66.

Kemmerling, Achim and Andreas Stephan (2002) 'The Contribution of Local Public Infrastructure to Private Productivity and Its Political-Economy: Evidence from a Panel of Large German Cities', Public Choice 113: 403-24.

Klingemann, Hans-Dieter, Richard I. Hofferbert and Ian Budge (1994) Parties, Policies, and Democracy. Boulder, CO: Westview Press.

Manow, Philip, Armin Schäfer and Hendrik Zorn (2004) 'European Social Policy and Europe's Party-Political Center of Gravity, 1957-2003', MPIfG Discussion Paper 04/6. 
Marks, Gary and Marco Steenbergen (2002) 'Understanding Political Contestation in the European Union', Comparative Political Studies 35(8): 879-92.

Mattila, Mikko (2003) 'Why Bother? Determinants of Turnout in the European Elections', Electoral Studies 22(3): 449-68.

Meltzer, Allan and Scott F. Richard (1991) 'Rational Theory of the Size of Government', in Allan Meltzer, Alex Cukierman and Scott F. Richard (eds) Political Economy, pp. 23-35. Oxford: Oxford University Press.

Persson, Torsten (2002) 'Do Political Institutions Shape Economic Policy?', Econometrica 70(3): 883-905.

Persson, Torsten and Guido Tabellini (2003) The Economic Effects of Constitutions. Cambridge, MA: MIT Press.

Persson, Torsten and Guido Tabellini (2004) 'Constitutions and Economic Policy', Journal of Economic Perspectives 18(1): 75-98.

Pollack, Mark A. (1995) 'Regional Actors in an Intergovernmental Play: The Making and Implementation of Economic Structural Policy', in Carolyn Rhodes and Sonia Mazey (eds) The State of the European Community, III: Building a European Polity? Boulder, CO: Lynne Rienner and Longman.

Reif, Karlheinz (1984) 'National Electoral Cycles and European Elections 1979 and 1984', Electoral Studies 3(3): 244-55.

Rodden, Jonathan (2002) 'Strength in Numbers? Representation and Redistribution in the European Union', European Union Politics 3(2): 151-75.

Rodden, Jonathan and Erik Wibbels (2002) 'Beyond the Fiction of Federalism: Macroeconomic Management in Multi-tiered Systems', World Politics 54(3): 494-531.

Roemer, John E. (2001) Political Competition: Theory and Applications. Cambridge, MA: Harvard University Press.

Sutcliffe, John B. (2000) 'The 1999 Reform of the Structural Fund Regulations: Multi-level Governance or Renationalization?', Journal of European Public Policy 7(2): 290-309.

Taggart, Paul and Aleks Szczerbiak (2002) 'The Party Politics of Euroscepticism in EU Member and Candidate States', Opposing Europe Research Network Working Paper No. 6.

Van der Eijk, Cees and Mark N. Franklin (eds) (1996) Choosing Europe: The European Electorate and National Politics in the Face of Union. Ann Arbor: University of Michigan Press.

Wittman, Donald (1983) 'Platform Motivation: A Synthesis of Alternative Theories', American Political Science Review 77: 142-57.

Zimmer, Christina, Gerald Schneider and Michael Dobbins (2005) 'The Contested Council: Conflict Dimensions of an Intergovernmental EU Institution', Political Studies Politics 53(2): 403-22. 


\section{About the authors}

Achim Kemmerling is a senior researcher in the research unit 'Labour Market Policy and Employment' at the Social Science Research Center Berlin (Wissenschaftszentrum Berlin für Sozialforschung, WZB), Reichpietschufer 50, D-10785 Berlin, Germany.

Fax: +49 3025491222

E-mail: Kemmerling@wz-berlin.de

Thilo Bodenstein holds the Jean Monnet Chair for European Integration at the Free University of Berlin (Freie Universität Berlin), Ihnestrasse 22, D-14195 Berlin, Germany.

Fax: +493083852357

E-mail: t.bodenstein@jmc-berlin.org 